\title{
THE BUDGET OF THE EUROPEAN UNION AND GREEN ENERGY: PERCEPTIONS, ACTIONS, AND CHALLENGES
}

\author{
Çă̆gaş CENGİZ*, Erdi KUTLU ${ }^{* *}$
}

Makale Geliş Tarihi-Received: 01.01.2021

Makale Kabul Tarihi-Accepted: 20.05.2021

DOI: $10.37093 /$ ijsi.950563

\section{ABSTRACT}

The European Green Deal has expanded the climate perspective of the European Union (EU) and put a sustainable and environmentally friendly energy strategy at the centre. For the first time in the history of the EU integration, the EU budget has been designed for prioritizing the climate strategy and conditioned in accordance with the climate targets. Within this context, in this study, the common budget priorities, Green Deal targets and internal/external challenges of the EU are addressed together, aiming to answer the questions to what extent the global climate change is perceived as an emergency by the EU and whether the EU's green transformation approach is sufficient and applicable. The study is conducted in the light of current literature and data on the EU's climate approach and financing instruments in order to answer these questions. The study concludes that although the climate model reflected in the EU's new budget is an important step in combating the climate crisis, difficulties could not be overcome due to the intra-EU dynamics/lack of consensus, and unless a systemic transition in

Dr., Dokuz Eylül University, European Studies, İmir/Turkey. cagdas.cengiz@deu.edu.tr, ORCID: 0000-0002-7606-5842. (Corresponding Author).

** PhD, Ege University, International Relations, İzmir/Turkey. erdikutluuu@gmail.com, ORCID: 0000-0003-4340-2969. 
Çağdaş CENGİZ, Erdi KUTLU

a global sense takes place, the dramatic transformation targeted by the Green

Deal would remain discursively assertive, but actionally ambiguous.

Keywords: European Union, Multiannual Financial Framework, Green Deal, Climate Crisis, Renewable Energy.

Jel Code: F30, N44, O52, Q28. 
The Budget of the European Union and Green Energy:

Perceptions, Actions, and Challenges

\section{AVRUPA BİRLİĞİ BÜTÇESİ VE YEŞİL ENERJİ: ALGI, EYLEM VE ZORLUKLAR}

\section{ÖZ}

Avrupa Yeşil Mutabakatı, Avrupa Birliği'nin (AB) iklim perspektifini genişletmiş ve sürdürülebilir, çevre dostu bir enerji stratejisini merkeze koymuştur. $A B$ bütçesi de entegrasyon tarihinde ilk kez iklim stratejisine öncelik verecek şekilde tasarlanmış ve iklim hedeflerine göre koşullandırılmıştır. Bu bağlamda bu çalışmada, küresel iklim değişikliğinin AB tarafindan ne ölçüde "acil bir durum" olarak algılandiğı ve AB'nin yeşil dönüşüm stratejisinin yeterli ve uygulanabilir olup olmadiğg sorularına yanıt verebilmek amacıyla, AB'nin ortak bütçe öncelikleri, Yeşil Mutabakat hedefleri ve Birlik içi/dışı zorluklar bir arada ele alınacak ve tartışılacaktır. Bu amaçla, AB'nin iklim yaklaşımı ve finansman araçlarına ilişkin mevcut literatür ve verilerden yararlanılmıştır. Çalışmada, AB'nin yeni bütçesine yansıyan iklim modelinin iklim kriziyle mücadelede önemli bir adım olmasına rağmen, Birlik-içi zorluklar aşılamadığı takdirde ve küresel anlamda sistemik bir geçiş olmaksızın, Yeşil Mutabakat'ın hedeflediği dramatik dönüşümün söylemsel olarak iddial fakat eylemsel olarak belirsiz kalacağı sonucuna varulmıştır.

Anahtar Kelimeler: Avrupa Birliği, Çok Yıllı Mali Çerçeve, Yeşil Mutabakat, İklim Krizi, Yenilenebilir Enerji.

Jel Kodu: F30, N44, O52, Q28. 


\section{INTRODUCTION}

The Green Deal has expanded the green energy perspective of the European Union (EU) and put a sustainable and environmentally friendly energy strategy at the centre. Instead of being dependent on fossil fuels, the new and greener energy strategy aims to create a fully integrated, interconnected, and digitalized energy single market. In this direction, for the first time in the history of the EU integration, the EU budget has been designed for prioritizing the climate strategy and conditioned in accordance with the climate targets. Moreover, considering the external dependence on fossil fuels, it is better understood how vital the gradual increase in renewable energy production is for the EU. For these reasons, the EU has made supply security in renewable energy one of its main political priorities in order to sustain its regional and global influence, and to maintain its claim to be the centre of gravity in global climate action.

Along with the NextGenerationEU initiative designed to accelerate the recovery after the COVID-19 Pandemic, the EU's new budget has become the largest stimulus package ever funded. Designed with a greener, more digital and more resilient European discourse, a total of 1.8 trillion Euros will be offered to essential financial opportunities for the recovery after the COVID-19 outbreak. In the new period that will last until 2027, it is planned that at least $30 \%$ of the EU budget will be spent for the protection of the climate and in this way the decarbonization commitments will be fulfilled. The new financial period, based on climate targets, aims to strengthen investments in European infrastructure networks and cross-border projects in the field of renewable energy through new funds.

Besides, the concept of renewable energy does not only have a climate-based meaning for the EU, it also refers to the opportunity to change the unsustainable conditions arising from dependence on fossil fuels and therefore foreign-source dependency in an economic sense. At this point, economic and geopolitical factors come to the fore along with supply security. The EU's overdependency on Russia in energy supply is the main factor that weakens the EU internally and externally. This reality, both economically and politically unsustainable, negatively affects the EU as a regional and global actor. In order to overcome this constraint, the EU had to make a choice that also has some significant implications such as accelerating the green 
The Budget of the European Union and Green Energy:

Perceptions, Actions, and Challenges

energy transition and reducing its dependence on third countries. Within this context, the common budget corresponds to the EU's main mechanism by which this choice is embodied and reflected on the field.

Taking all these dimensions into consideration, in this study, firstly, by examining the new budget of the $\mathrm{EU}$, it was discussed to what extent the issue of global climate change is vital in the perception of the EU. Then, the financial model and instruments of the EU for Green Deal and green energy issues were examined by making use of the current literature and data on the related subject. In this vein, the strengths and weaknesses of the climate model that the EU has already put forward were discussed. In the last section, the EU's geopolitical and economic contradictions and the dependency relationship, which reveals the unsustainable nature of this contradictory structure, were highlighted on the basis of its asymmetrical relationship with Russia. As a result, it was concluded that although the climate model reflected in the EU's new budget is an important step in combating the climate crisis, the dramatic transformation targeted by the Green Deal would remain discursively assertive but actionally ambiguous without a systemic transition in a global sense.

\section{INFERRING CLIMATE PERCEPTION FROM THE COMMON BUDGET OF THE EU}

The new budget of the EU covering the multiannual period of 20212027 is setting at a historical turn where the current global contradictions and difficulties intersect. A turning point which shows its face between the recent crucial developments: the global economic crisis, crisis of global politics, trade wars, humanitarian issues, migration waves, social upheavals, ultimately a pandemic (COVID19) and above all, on the verge of the climate crisis, which is the primary problem of all humanity.

From past to present, the EU has changed and transformed by transferring the effects of regional and global developments reflected in each financial period to its cyclical priorities, while maintaining its basic strategic discourse and policies. While the past budget period (2014-2020) was inevitably shaped under the shadow of the post-crisis 
Çağdaş CENGİZ, Erdi KUTLU

financial turmoil and the Euro Crisis, the 2021-2027 budget was also designed under the shadow of the economic regressions as well as the deepening political, social and environmental crises and of course the Brexit process. Within the new mutiannual financial period of the Union, the priorities set to cope with current challenges have considerably affected the composition, size and allocation of funds in the budget. The new period, which started with the discourse of "A Modern Budget for a Union that Protects, Strengthens and Defends", has been planned by focusing on the efficiency of budget headings and programs in practice. The EU budget represented the financial dimension of the Union's response to many deepened problems, from large-scale migration waves to new security threats and to global
warming. Thus, current dimensions such as research and development, youth, digital economy, border management, security and defense, climate change/crisis came to the fore as new priorities in the common budget. The new budget proposes to continue and strengthen the funding of deep-rooted programs for environment and climate action, and also includes support for measures promoting energy efficiency and clean energy. Therefore, whether viewed as an inevitable global agenda or a regional financial challenge, the environmental pollution and climate crisis/emergency continues to approach the centre of gravity of the Union's common policies and priorities, since the 1990s and after the Rio Summit. As a matter of fact, when the issue is analyzed in terms of budget, it is noteworthy that in the new financial period, the Union's contribution towards climate goals should be spread to a minimum of $25 \%$ of the expenditures and $30 \%$ before the end of the period, which is advocated by many different institutions and actors of the Union, especially by the European Parliament (Cengiz and Kurtar, 2019: 2-3).

The biggest and most controversial component of the financial framework is the 'natural resources and environment' chapter. In the new period, it is seen that targets such as modernized agriculture and maritime policies, climate action and protection of the environment, generalization of climate funds throughout the budget and greater integration of environmental targets are brought to the fore. Supporting elements such as security, quality, reasonable price, nutritional value and diversity within the new Common Agricultural Policy (CAP) reforms; It is understood that the resource of 365 Billion Euros, which focuses the environment and climate more at the centre, includes support for the transition to a fully sustainable agricultural 
The Budget of the European Union and Green Energy:

Perceptions, Actions, and Challenges

sector and the development of rural areas. As a matter of fact, in the new financial framework, the emphasis is on the need for a higher level environmental and climate target, which strengthens the conditionality principle for direct payments (Cengiz and Kurtar, 2019: 12). Despite the Commission's assertive rhetoric on this point, according to a report published by the British Grantham Climate Change and Environmental Research Institute within the London School of Economics and Political Science (2018), It has been determined that none of the EU member states (including France, as the pioneer of the process) have fully fulfilled their responsibilities in accordance with Paris Agreement to prevent the Greenhouse Gases (GHG) emissions that cause global warming. In addition, in the related scientific report, it was stated that only 16 of the 195 countries which are the signatories of Paris Climate Agreement in 2015- fully comply with the terms of the Agreement. It is also known that after the Climate Agreement, some countries with developed industries especially Germany who argue that the measures for GHG emissions are quite strict- are opposed to the more stricter criteria.

Following the approval of the European Parliament (EP), on 17 December 2020, the Council adopted the regulation setting out the 2021-2027 MFF (European Council, 2020). The new MFF is an important step for the EU. However, it is far from the 1.3\% GNP contribution demand of the EP for the long-term budget. In addition, it is debatable to what extent it is sufficient to be a turning point in combating climate change and inequalities. At this point, it is useful to look at the recent literature.

\section{Recent literature on current developments}

The COVID-19 outbreak has created a new agenda in terms of both the EU budget and climate priorities. Combating climate change was the common discourse before the pandemic. Despite the organic link between the destruction of nature and the pandemic, it seems that the biggest challenge in maintaining the European Green Deal as a priority policy today and in the current budget period is the COVID19 pandemic that affects the whole world and Europe since the first months of 2020. According to the Siddi, the economic stagnation caused by pandemic in Europe may be force the European Commission to cut the funds allocated to combat with climate change. To enact the 2050 climate-neutral target, a key component of the 
European Green Deal, the Commission proposed the first European Climate Law on 4 March 2020. Thus, the EU Draft Climate Law was presented before the first shutdown measures of the COVID-19 outbreak in Italy were taken (Siddi, 2020: 8). As the pandemic hit Europe and combating with it became the main priority, it was no surprise that the proposal for climate law was delayed. For this reason, although it was expected to be adopted in 2021, the priority of enactment was pushed to the background. In the same way, according to the Brodny and Tutak (2020: 2), the implementation of the Green Deal includes the preparation of a new climate law which all Member States must accept and then enforce. Otherwise, it would not meet the

In the aftermath of the COVID-19 outbreak, the future role of EU climate and energy policies in the energy transition has been somewhat shaken, too. In July 2020, the EU leaders agreed on the budget, whose mission is to boost the economy after COVID-19 outbreak, as well as actually advance some key EU goals, such as the climate initiatives. Many analysts welcomed the deal, citing it as the most environmentally friendly incentive ever. On the other hand, the deal came at a cost and resulted in cuts in key climate and environmental spending, the three key components of realizing the Green Deal and Digital Agenda. In particular, the Just Transition Mechanism was reduced from 40 billion Euros to 17.5 billion Euros resulting in a significant cut (European Parliament, 2021). As a result, the EU institutions have decided to continue the energy transition in the post-COVID-19 period as a way for the European economy to recover; besides, Member States will play an essential role in the presentation of national recovery plans, which should include the issue of the energy transition. What's more, national disputes will mean restrictions on the allocation of these funds and the allocation of funds to populations who will lose their wealth during the energy transition. On the other hand, according to the Hafner and Raimondi (2020), in the long run, if Europe is to become carbon neutral, decarbonisation of natural gas will be on the agenda. Regardless of all these challenges, the future of Europe, its societies and foreign relations will also need to be redefined and reconstructed with the ongoing energy transition.

In a similar vein, Hainsch et al. (2020: 304) argue that, optimal allocation of resources and proportional sharing of burden should be 
The Budget of the European Union and Green Energy:

Perceptions, Actions, and Challenges

perceived as an essential component of the green transition. There is a need for cooperation between all member states and regions that would be more burdened. As the transition to renewable energy continues, it is important that the EU and Member States focus on initiatives that together reinforce economic recovery, environmental sustainability and of course climate action.

Equal burden sharing in the green transition also means fair distribution of funds. The European Green Deal can profoundly and successfully transform the Union's economy, if it remains the top policy priority in both the medium and the long term, particularly in relation to the climate agenda at regional and global level, and if its implementation starts with a well-founded reorientation of financial supports and the allocation of funds (Sikora, 2021: 683).

Oberthür and Dupont (2020: 2-3) state that by implementing ambitious strategies, the EU has already performed considerable strides in fulfilling its own decarbonization aim for 2050. In the first decade of the 21st century, climate policy acquired particular impetus In fact, the EU is one of the leading actors dealing with climate change and trying to minimize GHG emissions, as European countries and the rest of the world seem to have serious environmental problems such as climate impacts and severe weather conditions. In line with the 2030 climate and energy targets, the EU has pioneered international efforts for the success of the Paris Agreement on reducing GHG emissions. In addition, the EU has recently reinforced its priority to become the first mainland to be climate neutral by 2050 and has made its most ambitious initiative (Şahin et al., 2021: 42).

It is known that the transport sector is the main driver of climate change both globally and regionally. When looking at the current level in the EU, emissions related to transport are higher than in the 1990s. According to Haas and Sander (2020), who addresses the Green Deal's decarbonisation targets in terms of the transportation sector, extensive decarbonization is not possible without a major change in power balance. 
Çağdaş CENGİZ, Erdi KUTLU

\section{SUSTAINABLE REALITY: ACTIONS OF GREEN DEAL AND GREEN ENERGY}

The EU will have some objections and actions against fossil oil energy dependency to the third countries and natural catastrophe of climate change which could be reduced in the long term. The new energy strategy includes important principles which will be in line with climate strategy. These principles are sustainbility, competitiveness and energy supply security. Natural deterioration and climate crisis are representing EU's common sensitivity as a soft power. EU wants to be a global leader in tackling the climate crisis and using green energy. The EU's new green srategy covers long term growth strategy that will transform the EU into a resource efficient and energy selfsufficient entity. It is claimed that, no net GHG emissions by 2050 is the main object with reducing resources use for economic growth and no one or no place is going to be left behind with new green growth. While $30 \%$ of the budget (nearly 550 billion Euros) was set aside for climate protection in the new fiscal period, it was also planned to fulfill decarbonization commitment. In the new financial period, indexed to climate action for the first time in the history of EU integration, 42.3 billion Euros was planned to allocate to support investments in European infrastructure networks, and the Connecting Europe Facility was strengthened. New financial supports, including a new window for cross-border projects related to renewable energy, has been designed.

The EU declares that the Green Deal is the new strategy to make the EU's economy and so the future of next generation sustainable. The Green Deal will be in line with its action plan. Removing fossil resource use by clean energy, cutting pollution, restoring ecosystem also is the EU's main targets with new balanced and reinforced circular economy (European Commission, 2020a). According to the Commission; the Green Deal aims to protect, secure and develop Union's natural capital, protect health and wellbeing of the EU citizens from enviromental risks. Innovating the EU's economic sectors and industries will have to include people and all regions which would be affected most negatively by economic transformation challenges. It needs people's consent and collective work of local, regional, national authorities and civil society with the EU's all institutions and bodies. Costs of additional reductions in emissions are indicated as a hard challenge. Public investment and much efforts 
The Budget of the European Union and Green Energy:

Perceptions, Actions, and Challenges

should be increased to finance climate and environmental policies to protect vulnerable sectors and citizens. As a supranational Union with its own and common policies, the EU organizes all member states' policies melting them in one pot. The EU Commission's Green Deal Communication shows a roadmap for the key policies and strategies required to succeed European Green Deal. As the challenges are complicated and interlinked, the Green Deal can be updated to solve for new problems. It will require to merge all efforts and intense coordination all local, regional, national and supranational policy areas (European Commission, 2019a).

The Green Deal has become one of the main part of the EU Commission's policy to implement United Nation's (UN) 2030 Agenda and sustainable development goals. It is also in same path and line with the EU Commission's president Ursula Von Der Leyen's political guidelines. As she said in her declaration: "I want Europe to strive for more by being the first climate-neutral continent" (von der Leyen, 2019). At this point 2030 UN Sustainable Development Goals will be at the core of the EU's policy making process and action in the new budget period. Commission's Green Deal Action Plan presents financing tools needed. As the President of Commission said Union's objective is making Europe climate neutral step by step until 2050. The EU Commission have proposed the EU Climate Pact to get succeed green deal political objectives as legal obligation all across the Europe. Every sector of economy has to get real actions and use these paths; i) investing in green-friendly technologies, ii) assisting industry and sectors for innovation, iii) progress working climate with green energy, iv) spread of eco-friendly cleaner, healthier and cheaper public and private transport, v) make carbon free the all energy sectors, vi) working with international in accordance with universal UN Climate Goals, vii) transform buildings for more energy saving.

The EU will provide financial and technical support in accordance with the Green Deal to tackle climate change to the most affected citizens, areas and countries in the Union. The Green Deal Strategy has a financial program which calls "Just Transition Mechanism". Through this mechanism, more than $€ 100$ billion was planned to be provided for most of the affected locations and sectors during the 2021-2027 EU Budget period (European Commission, 2020b). However, after the recovery plan, a significant cut was made by 
reducing the Just Transition Mechanism from 40 billion Euros to 17.5 billion Euros.

Figure 1. The EU Green Deal in the context of the Sustainable Europe Investment Plan.

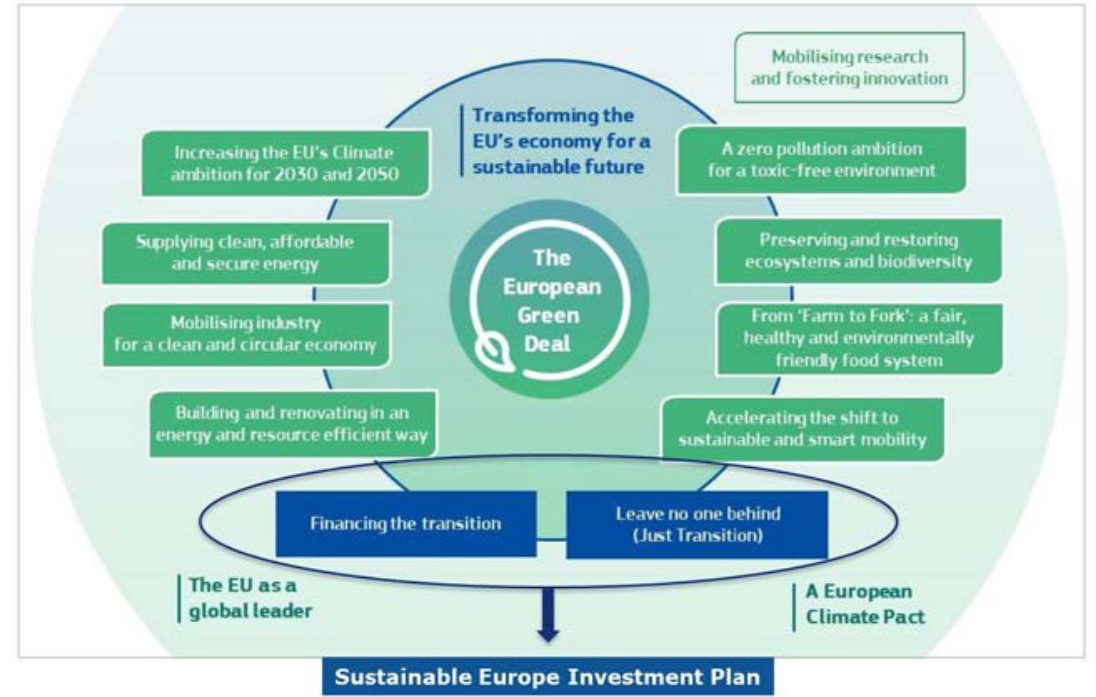

Source: European Commission, 2020c.

As can be seen from Figure 1, The European Green Deal Investment Plan is aiming to transform current EU economic models to green economy through increasing the EU's climate ambition for the 2030 and 2050, supplying clean and affordable secure energy, mobilizing industry for a clean circular economy, building and renovating in a resource efficiency, preserving and restoring ecosystems and biodiversity, providing a fair, healthy and environmentally friendly food system, and accelerating the shift to smart and sustainable mobility transition, to make the EU a global leader with its climate pact. To ensure this, in the 2021-2027 budget period 503 billion Euros will be transfer for climate and environment actions and 25 billion Euros for in the name of EU Emissions Trading System (ETS) Funds directly, as can be seen from Figure 2. At least 1 Trillion Euros will be used in investing green economy public and private totally. Green Deal Assistance mechanism is combined public and private sectors. This includes; i) capital from the EU and member countries' budget, ii) 
The Budget of the European Union and Green Energy: Perceptions, Actions, and Challenges

public and private sector investments, iii) additional measures to safeguard and progress green public and private investments, iv) technical assistance to assist with private investors which will be part of sustainable investments and projects and v) additional EU funds (European Commission, 2020d).

Figure 2. EU Green Deal Investment Tools (private and public combined), EUR.

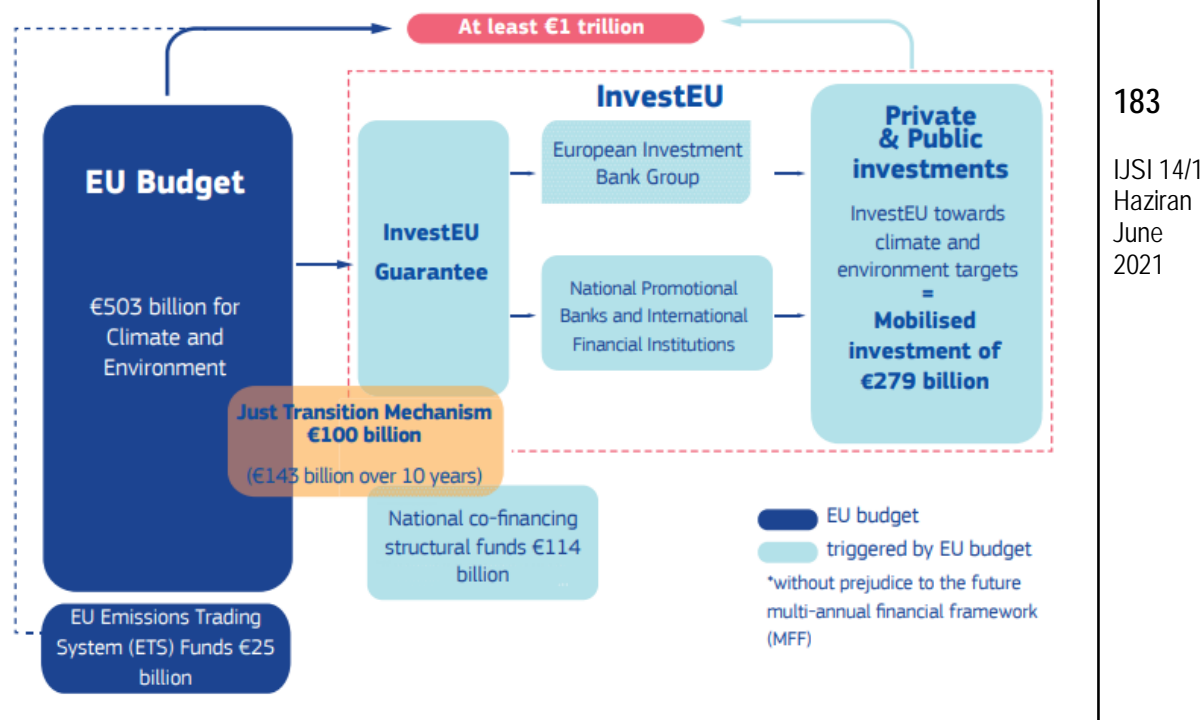

Source: European Commission, 2020b.

In the next green transforming era, for most vulnerable and affected areas, Executive Vice-President of the European Commission for the European Green Deal Frans Timmermans has stated that; "We must show solidarity with the most affected regions in Europe, such as coal mining regions and others, to make sure the Green Deal gets everyone's full support and has a chance to become a reality." (European Commission, 2019b). Additionally, in May 2020, the Commission presented a revised proposal for the 2021-2027 MFF to support the recovery from the COVID-19 outbreak and prepare for the next generation of the future. As can be seen from Table 1, the ambitious spending target for climate action is increasingly essential for a balanced recovery package and 
remains in place in the revised proposal for the long-term common budget (European Commission, 2020e).

Table 1. Size of MFF and Next Generation EU (July 2020 EU Council compromise), EUR.

\begin{tabular}{ll}
\hline Next Generation EU 2021-2023 & Temporary Reinforcement \\
& 750 billion Euros
\end{tabular}

1.074,3 billion Euros

\begin{tabular}{ll}
\hline MFF 2021-2027 & $1.074,3$ billion Euros \\
\hline Overall Climate Target & $30 \%$ Applicable to the Total Amount
\end{tabular}

Source: European Commission, 2020e.

Based on the Commission proposal, in 17-21 July 2020, European Council sets an overall climate target of $30 \%$ applicable to the total amount of expenditure from the 2021-27 MFF and NextGenerationEU, the main initiative for implementing the recovery package (European Commission, 2020f).

To evaluate from a critical point of view, it is seen that Green Deal and similar new order strategies have no contradictions with economic growth approaches. According to the Purkis (2020), the examples from recent decades show that such strategies for resolving the ecological crisis have led to a new form of exploitation each time. For example, the market-based offsetting or equalization policies (most known one is the carbon market), are generally policies that cover all living life and make the earth uniform by eliminating biodiversity. The Kyoto Protocol, which entered into force in 2005, and all international climate summits since then, has reduced the solution of ecological damages just into a carbon reduction model, and offered mechanisms those see the carbon market as the only protection tool. All of these are designed with the understanding of the domination of nature by the economic mind. With this understanding, an exchange value is appraised to the very different and incomparable features and functions of nature to the extent that it is suitable for profit. It is argued that the ecological damage created by investment in one place can be balanced with investment made to protect the ecology elsewhere. The 'elsewhere' referred to here is always the poor geographies deeply in debt. 
The Budget of the European Union and Green Energy:

Perceptions, Actions, and Challenges

Graph 1. The top 20 companies have contributed to $480 \mathrm{bn}$ tonnes of carbon dioxide equivalent since 1965 (billion tonnes of carbon dioxide equivalent).
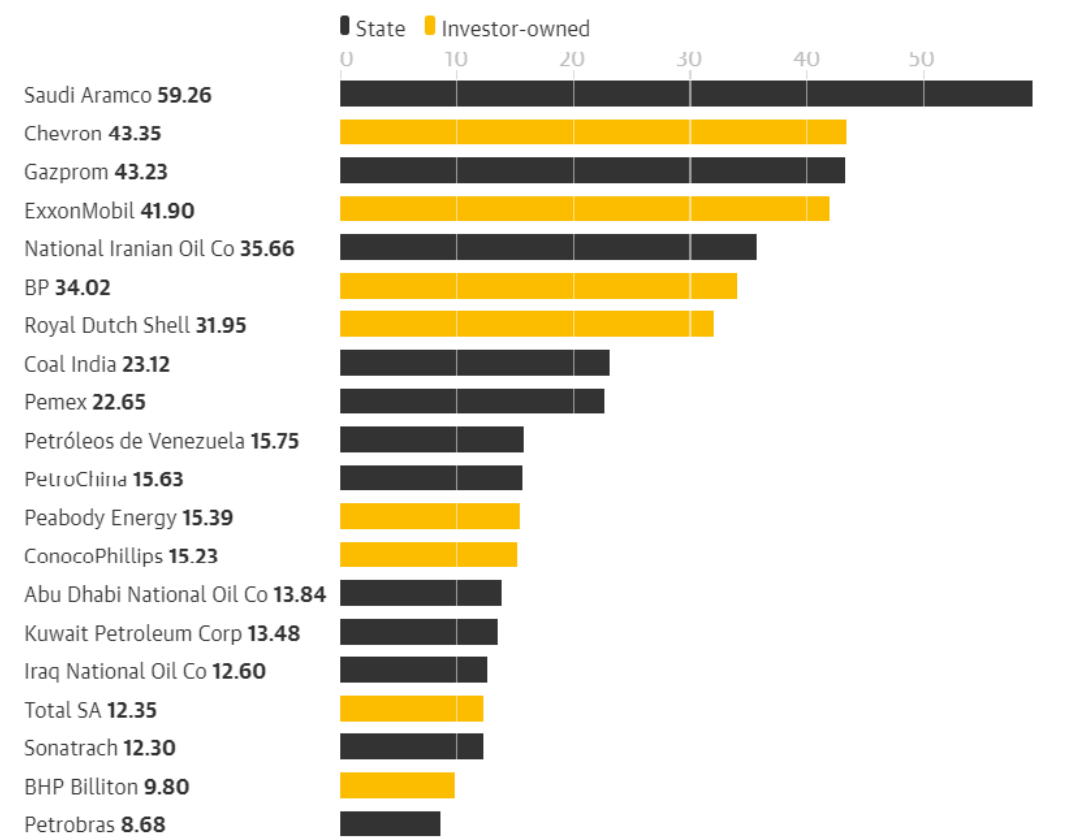

As clearly seen from Graph 1, findings on the climate crisis demonstrate the role of fossil fuel companies which are responsible for more than one-third of whole greenhouse gas emissions in the modern era. This top 20 list generated $90 \%$ of emissions from products such as oil, jet fuel, natural gas and thermal coal. The remaining ratio is the extraction, refining and distribution of finished fuels. On this point Mann argues that, "the great tragedy of the climate crisis is that seven and a half billion people must pay the price - in the form of a degraded planet - so that a couple of dozen polluting interests can continue to make record profits. It is a great moral failing of our political system that we have allowed this to happen." (Guardian, 2019).

Despite this reality, if we look at the websites of the multinational companies that pollute the world the most, it is possible to see that 
each of them is carbon neutral thanks to their offsetting mechanisms. These companies are carbon neutral, doing their dirty production elsewhere in the world, and still making so-called 'environmental' carbon-holding investments that cause irreversible damage to nature elsewhere. In this manner, the underdeveloped geographies of the world have been turned into carbon waste by developed countries and their multinational companies, and the poorest classes living in these geographies suffer the most. For example, thanks to the carbon market, multinational companies continue to pollute by establishing thermal power plants in other parts of the world, opening gold mines, and continuing to produce dirty industry. They are able to save the so-called carbon dioxide equivalent of the pollution created by these projects with the projects they make in other geographies (Purkis, 2020).

\section{UNSUSTAINABLE REALITY: THE EU'S CHALLENGING ENERGY DEPENDENCY}

The foundations of the supranational structure that the EU has reached today was taken with the integration initiatives in energy sectors through the European Coal and Steel Community (ECSC) and the European Atomic Energy Community (EURATOM). Despite this historical background, by this time, the EU could not develop a common energy policy that synchronizes all its members, and could not prevent foreign dependency in the energy field (Arman and Cengiz, 2020: 127). The issue of transition to renewable energy, which is of vital importance to the EU, opens a new context for the EU in this sense as well.

For the EU, renewable energy is a set of alternative processes that will reduce dependence on fossil fuels with a high external dependency. Dependence on Russia, due to factors such as geopolitics and supply constraints, weakens the EU at regional and global level. Therefore, increasing renewable energy production is vital for the EU as it will reduce energy dependency. As a regional and at the same time a global actor, the EU considers ensuring supply security in renewable energy one of its main political priorities in order to maintain its global influence and its claim to be the main actor in climate action (Cengiz and Kutlu, 2020). 
The Budget of the European Union and Green Energy:

Perceptions, Actions, and Challenges

The EU imports natural gas, oil and solid fuels substantially from Russia. That means, the EU is excessively dependent on Russia in terms of energy. This economic dependency inevitably affects political relations. In this vein, Russia uses its energy weapon as a political and economic power. The EU, on the other hand, aims to diversify its energy sources and reduce its dependence on Russia (Güneş and Arslan, 2018: 51-52). The EU's energy dependency on abroad is approximately at the rate of $\% 60$ (see Graph 2). It should also be noted that the crude oil was the mainly imported product which equaled almost two thirds of energy imports of the EU, and it is followed by natural gas (\%25) and solid fossil fuel (\%8).

Graph 2: EU's energy dependency (\%), 2018.

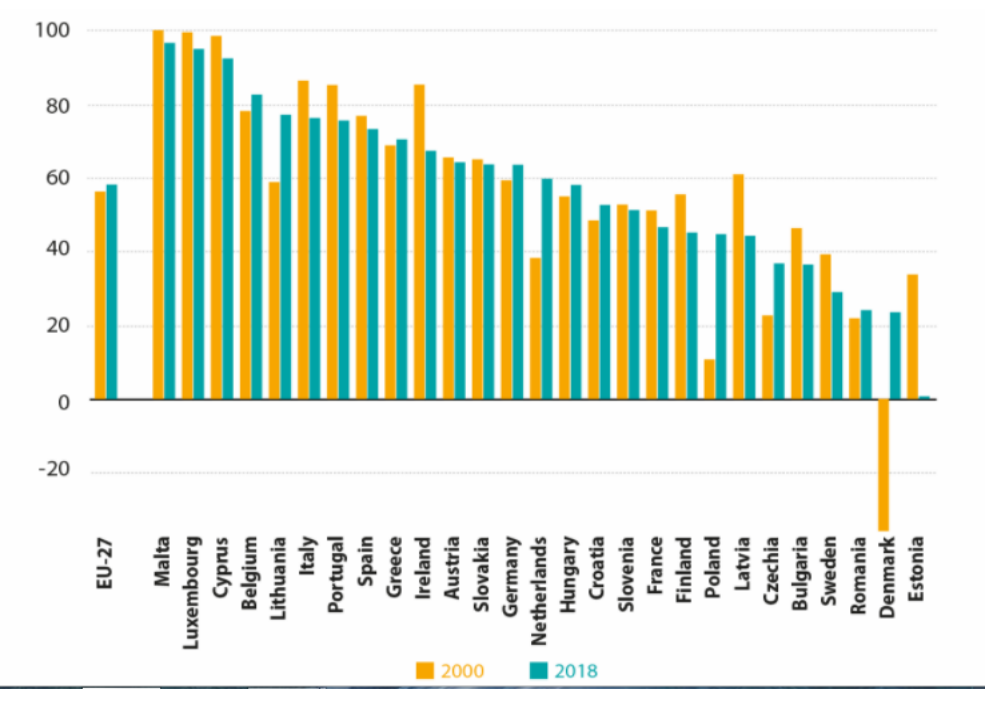

Source: European Commission, 2020g.

If the EU's energy dependency stands in same degree, Union's energy supply may become more volitile and threatened in any time when the political sphere escalates. Then EU's prestige and soft power capability can be downsized and it would pose a challenge for EU's future. The only condition for reducing the EU's dependency on abroad especially on Russia is to increase the EU's renewable energy capacity and disseminate it across to the all continent. As can be seen from Graph 3, oil products (crude oil and petroleum) are still the 
major energy sources for the EU's economy, despite a long-term downward trend, while natural gas remains the second largest energy source. Yet it is remarkable that the contribution of renewables is constantly increasing, even surpassing solid fossil fuels in the end.

Graph 3. Gross inland energy consumption by fuel, EU-27, 1990-2018 (million tones).

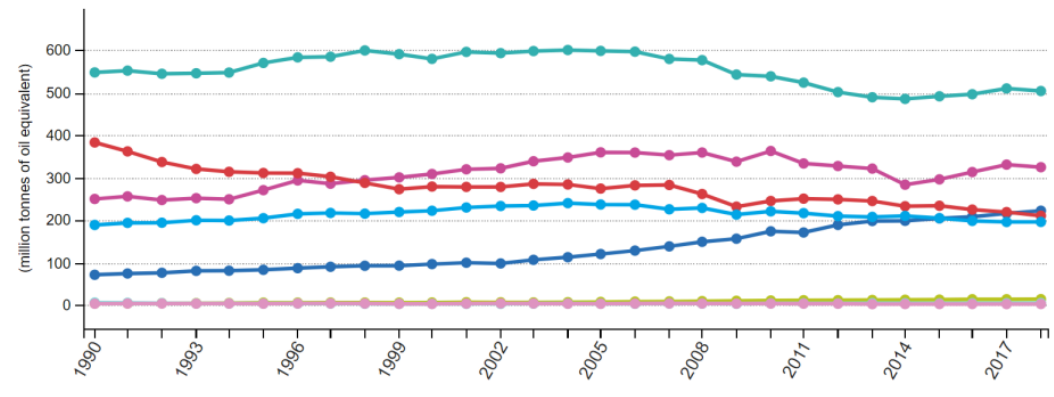

- Oil and petroleum products Natural gas Renewables and biofuels Non-renewable waste

Source: Eurostat, 2020a.

On the other side as can be seen from Figure 3, Russia was the main energy exporter to the EU in general manner and for each three products as well: crude oil (\%30), natural gas (\%40) and solid fossil fuel $(\% 42)$.

Figure 3. EU imports from Russia by energy products, 2018 (\%).

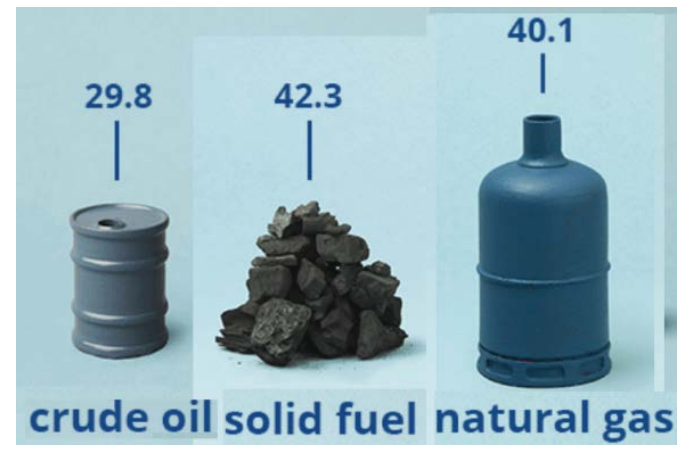

Source: European Commission, 2020g. 
The Budget of the European Union and Green Energy:

Perceptions, Actions, and Challenges

Graph 4 clearly shows that, the energy relationship between the EU and Russia can be characterized as an uneasy trade partnership. Despite being geopolitical competitors, they are closely interdependent one another. The EU depends on Russia for its energy deficiency. Russia depends on the EU for a regular income revenue. Russian economy relies upon energy exports, in another words, its sustainable well-being relies upon to secure demand for its hydrocarbons. This means, the European market mostly represents that security (Popovic, 2020).

Graph 4. Energy in the EU's trade volume with Russia, 2009-2019.

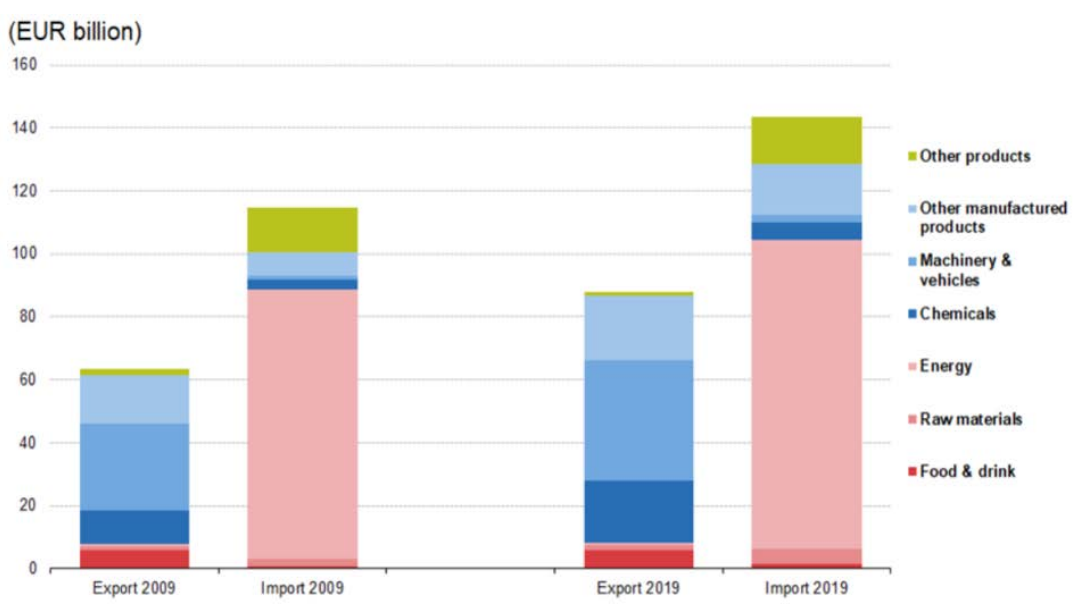

Source: Eurostat, 2020b.

As can be seen from Graph 5, the primary energy production of the Union was distributed across a number of different energy sources, the primary importance of which in terms of the size of Union's contribution were the renewable energy sources, accounting for more than one third $(34.2 \%)$ of the Union's total production. With $30,8 \%$ of the overall primary energy output, nuclear energy was second. The proportion of solid fossil fuels (18.3\%, mainly coal) was just under one fifth and the proportion of natural gas was close to one tenth (9.3 $\%)$. The only other significant source of primary energy production was crude oil (3.4\%) (Eurostat, 2020c). 


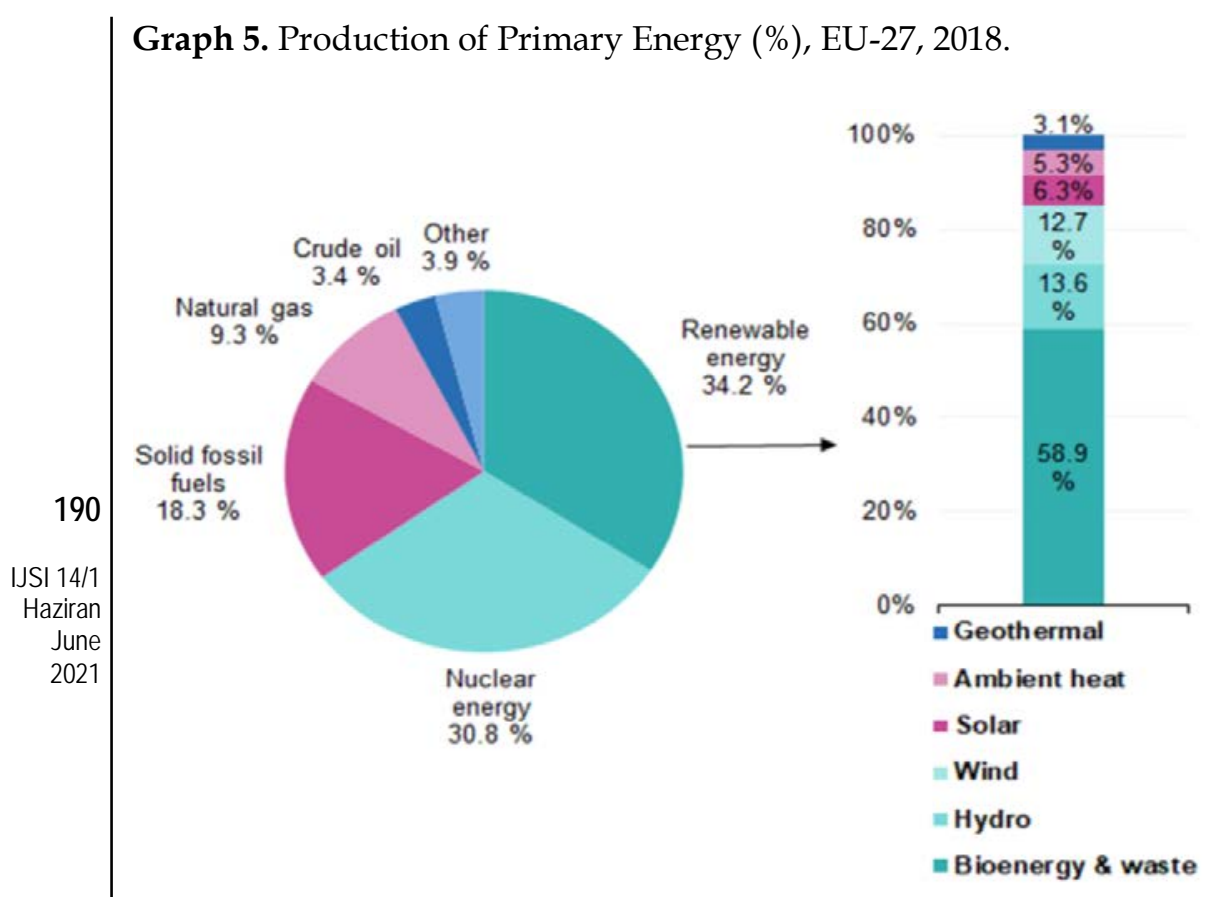

Source: Eurostat, 2020d.

It can be understood that the EU's dependence on a limited number of energy suppliers for the main energy products, particularly Russia, would be result in a go towards renewable resources via in search of the expansion of reliance on renewable energy technology, seeking after new suppliers, reaching relatively high hydrocarbon energy stocks, finding new solutions to abate environmental pollution, as well as applying extensive reduction policies by the way of energy conservation, and efficiency. But the impact of these initiatives remains limited, as the European dependence on abroad has not been reduced to a reasonable level. However it can be expected that the potentiality of improving the EU's energy security is still relatively high, that just because the EU's strategy is characterized by high level of integration and it is wide-ranging when it comes to covered issues to include both providing resources and environmental sustainability (Elbassoussy, 2019). 
The Budget of the European Union and Green Energy:

Perceptions, Actions, and Challenges

\section{CONCLUSION}

The Green Deal includes much more comprehensive and fundamental steps than the EU's previous goals and programs in terms of energy and environment. It is not content just with a climate action, but offers a roadmap that prioritizes all environmental measures such as biodiversity, waste management, air pollution and green energy, by targeting a circular economic model. There is no other international actor yet presented a transformation strategy of this level as the 2030 and 2050 targets. Green Deal has the potential not only to limit the issue of combating the climate crisis to its own geography, but also to transform its strategy into action on a global scale. The EU's climate neutral strategy offers a special opportunity to saving on by eliminating fossil fuel imports and to become a stronger EU that ensures security in its energy supply. On the other hand, the climate neutrality strategy is not a goal that can be reached with just a populist discourse. As long as public funds continue to be used on fossil fuels, meeting emissions targets will be difficult for the EU. The EU should invest in energy saving and renewable energy projects rather than funding expensive and unnecessary fossil fuel projects. To ensure that funds are allocated for the transition to green energy and related infrastructures, and that these projects are in line with the Paris Agreement, the EU needs to make a change in its rules that determine which energy projects should be fund.

The 2021-2027 budget of the EU has blazed a trail in combating the climate crisis. The EU can transform this common financial practice into a global model by using both its sui generis structure and its famous soft power feature. Indeed, the transformation targeted by the Green Deal consensus is discursively assertive, but actionally ambiguous. In this vein, one can argue that any strategy that does not represent a truly systemic transformation will correspond to an unconvincing political discourse. Climate change is literally a global crisis and has reached at the emergency action level. By adhering to the classical production and consumption patterns, the desired progress will not be achieved in terms of climate, environment or green energy mainstreaming. The human being is now at the stage of making a decision between accepting the fact that we are in a war that we destined to lose even if we win, and continuing our stubbornness. This is an existential decision that will direct our own future. One may not deny that a small common budget in quantitative terms has more 
symbolic rather than a material significance. Therefore, the new MFF of the EU and the weight of the climate action component within this framework should only be considered as a starting point.

The current attitude of the EU Parliament about energy and climate matters, which raises the bar, is hopeful at the point reached. All kinds of approaches that focus on sustainability in climate, environment and energy issues should be supported. However, this vital area of struggle has economic, social and political dimensions. Undoubtedly, the concept of 'time' corresponds to a fourth dimension in this context of reality too. At the same time, the 2050 projection does not represent a certainty, quite the reverse, represents a relative distance, just like the previous deadlines, or as the decisions taken in optimistic meetings in the past which were not reflected on the field. Green transformation can only become concrete with green growth (even degrowth) and green energy revolutions. This concreteness requires the questioning of production patterns, profit maximization and consumerism in terms of economic transformation. In terms of social transformation, it requires resisting neoliberal impositions of relations of production such as flexibilization, privatization and deregulation. Above all, it makes inevitable to mobilize a global will, solidarity and a fundamental systematic criticism in the political sense. This requires a common leap of consciousness and a global transition (not just a regional one) that goes beyond the will of the EU alone, and will spread to all continents and peoples. The action that will lead this transition is not a single state or a regional integration, but the cross-border solidarity of the courageous social opposition that can take a risk of struggle with the states and multinational corporations which are primarily responsible for the exploitation of the nature. 
The Budget of the European Union and Green Energy:

Perceptions, Actions, and Challenges

\section{REFERENCES}

Arman, M. Necip; Cengiz, Çağdaş (2020). “Harmonisation of Western Balkan Countries with the European Union Energy Policies: The Berlin Process and Beyond". Niğde Ömer Halisdemir Üniversitesi Sosyal Bilimler Enstitüsü Dergisi, 2(2), 126-137.

Brodny, Jaroslaw; Tutak, Magdalena (2020). “Analyzing Similarities between the European Union Countries in terms of the Structure and Volume of Energy Production from Renewable Energy Sources". Energies 2020, 13(4): 913.

Cengiz, Çağdaş; Kurtar, Adem (2019). “Multiannual Financial Framework for 2021-2027: The Reflections of Current Challenges in European Union on Budget Priorities". Journal of Yaşar University, 14 (Special Issue on Business and Organizational Research), 1-17.

Cengiz, Çağdaş; Kutlu, Erdi (2020). “The New Common Budget of the European Union in the Axis of the Perception of Climate Crisis and the Conversion to Renewable Energy", EFE'2020 Abstract Book. (http:/ / 2020.efecongress.org/wp-content/uploads/2020/12/efe2020-bookof-abstracts-12-01-2021.pdf) (Accessed: 12.02.2021).

Elbassoussy, Ahmed (2019). “European Energy Security Dilemma: Major Challenges and Confrontation Strategies". Review of Economics and Political Science, 4(4), 321-343.

European Commission (2019a). "The European Green Deal”. Communication from the Commission COM(2019) 640 Final, 11.12.2019, Brussels. (https://eurlex.europa.eu/legal-

content/EN/TXT/?qid=1596443911913\&uri=CELEX:52019DC0640\#document 2) (Accessed: 01.10.2020).

European Commission (2019b). “The Just Transition Mechanism: Making Sure No One is Left Behind". (https://ec.europa.eu/info/strategy/priorities-20192024/european-green-deal/actions-being-taken-eu/just-transitionmechanism_en) (Accessed: 01.10.2020).

European Commission (2020a). "A European Green Deal: Striving to be the First Climate-Neutral Continent". (https://ec.europa.eu/info/strategy/ priorities-2019-2024/european-green-deal_en) (Accessed: 01.10.2020).

European Commission (2020b). “The European Green Deal Investment Plan and Just Transition Mechanism Explained". (https://ec.europa.eu/ commission/presscorner/detail/en/qanda_20_24) (Accessed: 01.10.2020).

European Commission (2020c). "European Green Deal Investment Plan". Communication from the Commission, $\operatorname{COM}(2020) 21$ final. (https://eurlex.europa.eu/legal- 
content/EN/TXT/HTML/?uri=CELEX:52020DC0021\&rid=7) (Accessed: 01.10.2020).

European Commission (2020d). "The European Green Deal: Investing in a Climate-Neutral and Circular Economy". (https:/ /ec.europa.eu/commission/presscorner/detail/en/fs_20_40) (Accessed: 01.10.2020).

European Commission (2020e). “2021-2027 Long-term EU Budget \& Next Generation EU". (https://ec.europa.eu/info/strategy/eu-budget/long-termeu-budget/2021-2027_en) (Accessed: 01.10.2020).

European Commission (2020f). "Supporting Climate Action through the EU Budget". (https://ec.europa.eu/clima/policies/budget/mainstreaming_en) (Accessed: 01.10.2020).

European Commission (2020g). "From Where Do We Import Energy and How Dependent Are We?" (Energy Dependency)". (https:/ /ec.europa.eu/eurostat/cache/infographs/energy/bloc-2c.html) (Accessed: 01.10.2020).

European Council (2020). "Long-Term EU Budget 2021-2027 and Recovery Package". (https://www.consilium.europa.eu/en/policies/the-eubudget/long-term-eu-budget-2021-2027/) (Accessed: 01.10.2020).

European Parliament (2021). "Just Transition Fund". 'EU Legislation in Progress' Briefing. (https://www.europarl.europa.eu/RegData/etudes/BRIE/2020/646180/EP RS_BRI(2020)646180_EN.pdf) (Accessed: 01.06.2021).

Eurostat (2020a). "Energy Statistics. Statistics Explain". (https://ec.europa.eu/eurostat/statistics-explained/index.php/Energy_ statistics_-_an_overview) (Accessed: 01.10.2020).

Eurostat (2020b). "Russia-EU International Trade in Goods Statistics". Statistics Explained. (https://ec.europa.eu/eurostat/statisticsexplained/index.php/Russia-EU) (Accessed: 01.10.2020).

Eurostat (2020c). "Energy Production and Imports. Statistics Explained". (https:/ /ec.europa.eu/eurostat/statistics-explained/pdfscache/1216.pdf) (Accessed: 01.10.2020).

Eurostat (2020d). "Production of Primary Energy, EU-27, 2018". Statistics Explained.

(https:/ /ec.europa.eu/eurostat/statisticsexplained/index.php?title=File:Prod uction_of_primary_energy,_EU27,_2018_(\%25_of_total,_based_on_tonnes_of_ oil_equivalent).png\&oldid=490390) (Accessed: 01.10.2020).

Guardian (2019). "Revealed: The 20 Firms Behind a Third of All Carbon Emissions". October 9th, 2019, (https://www.theguardian.com 
/environment/2019/oct/09/revealed-20-firms-third-carbon-emissions) (Accessed: 14.02.2021).

Güneş, Mehmet; Arslan, Tayfun (2018). “Triangle of European Union, Russia and Turkey on Energy Dependency and The Region of Eastern Mediterranean". International Journal of Humanities and Education, 4(4), 32-60.

Haas, Tobias; Sander, Hendrik (2020). “Decarbonizing Transport in the European Union: Emission Performance Standards and the Perspectives for a European Green Deal". Sustainability, 12(20), 1-15.

Hafner, Manfred; Raimondi, P. Paolo (2020). "Priorities and Challenges of the EU Energy Transition: From the European Green Package to the New Green Deal". Russian Journal of Economics, 6(4), 374-389.

Hainsch, Karlo; Göke, Leonard; Kemfert, Claudia; Oei, Pao-Yu; von Hirschhausen, Christian (2020). "European Green Deal: Using Ambitious Climate Targets and Renewable Energy to Climb Out of the Economic Crisis". DIW Weekly Report, 10(28/29), 303-310.

London School of Economics and Political Science (2018). “Aligning National and International Climate Targets". Grantham Institute. (http://www.lse.ac.uk/GranthamInstitute/) (Accessed: 01.10.2019).

Oberthür, Sebastian; Dupont, Claire (2015). Decarbonization in the European Union: Internal Policies and External Strategies. Basingstoke, UK: Palgrave Macmillan.

Popovic, Nemanja (2020). “The Energy Relationship Between Russia and the European Union”. E-International Relations. (https://www.eir.info/2020/02/24/the-energy-relationship-between-russia-and-theeuropean-union/) (Accessed: 01.10.2020).

Purkis, Semra (2020). "Crisis Exit Strategy and New Green Deal". Ecology Union, (https://ekolojibirligi.org/krizden-cikis-manifestosu-ve-yesil-yeniduzen/) (Accessed: 01.10.2020).

Sahin, Göktuğ; Taksim, M. Ali; Yitkin, Burak (2021). “Effects of the European Green Deal on Turkey's Electiricity Market". The Journal of Business, Economic and Management Research, 4(1), 40-58.

Siddi, Marco (2020). The European Green Deal: Assessing its Current State and Future Implementation. FIIA Working Paper 114.

Sikora, Alicja (2021). “European Green Deal - Legal and Financial Challenges of the Climate Change". ERA Forum, 21, 681-697.

von der Leyen, Ursula (2020). "Political Guidelines for the Next European Commission 2019-2024". (https://ec.europa.eu/commission/sites/betapolitical/files/political-guidelines-next-commission_en.pdf) (Accessed: 01.10.2020). 
Çağdaş CENGİZ, Erdi KUTLU

\begin{abstract}
ÖZET
Bu çalışmada, $A B^{\prime}$ nin ortak bütçesine dair öncelikler, Yeşil Mutabakat ile öne koyduğu hedefler ve bu anlamda karşılaştığı içsel/dışsal zorluklar bir arada ele alınarak, küresel iklim değişikliğinin $\mathrm{AB}$ tarafından ne ölçüde bir "acil durum" meselesi olarak algılandığı ve $A B^{\prime}$ nin yeşil dönüşüme ilişkin yaklaşımının ne derece yeterli ve uygulanabilir olduğu tartışılmıştır. Bunun için öncelikle, yeni ortak bütçe özelinde küresel iklim değişikliği gerçeğinin $\mathrm{AB}$ algisında ne derece yaşamsal bir konuya karşlık geldiği değerlendirilmiştir. Ardından, Yeşil Mutabakat ve yeşil enerjiye geçiş bağlamında Birliğin finansal modeli ve araçları incelenmiştir. Bu yolla, $A B$ tarafından uygulamaya başlanan iklim modelinin güçlü ve zayıf yönleri ortaya konulmaya çalışılmıştır.

IJSI 14/1

Bu boyutların yanı sıra yenilenebilir enerjiye geçiş, AB için yalnızca iklim hedefleri özelinde bir anlam taşımayıp, aynı zamanda fosil yakıtlara bağımlılıktan kaynaklanan sürdürülemez ekonomik koşullardan ve dolayısıyla dışa bağımlılıktan çıkışı temsil etmektedir. Enerji tedariğinde Rusya ile olan aşırı bağımlılık ilişkisi Birliği içeride ve dışarıda zayıflatan asli faktör olarak belirginleşmekte, dolayısıyla gerek ekonomik gerekse politik anlamda sürdürülemez bir zorluğu ifade etmekte ve bölgesel/küresel düzeyde bir aktör olarak Birliğin potansiyel etkinliğini olumsuz yönde etkilemektedir. $\mathrm{Bu}$ bağlamda $\mathrm{AB}$, yeşil enerjiye geçişi hızlandırmak ve enerji alanında dışa bağımlılığı azaltmak gibi aynı eksende ve iki boyutlu bir dönüşümün eşiğine gelmiştir. Bu dönüşümün boyutları ve dinamikleri, Birliğin en açık irade beyanı ve bu anlamda sahaya yansıyan en somut mekanizması olan ortak bütçesinde saklıdır.

Çalışma, $A B^{\prime}$ nin iklim yaklaşımı ve finansman araçları üzerine güncel literatür ve veriler 1şı̆̆ında gerçekleştirilmiştir. Öyle ki, COVID-19 pandemisinden sonra kıtasal ölçekte toparlanmayı hızlandırmak adına tasarlanan NextGenerationEU kurtarma fonunun da dahil edilmesiyle birlikte ortak bütçe, entegrasyon tarihindeki en kapsamlı teşvik paketi haline gelmiştir. Böylece daha yeşil, daha dijital ve daha dirençli bir Avrupa söylemiyle ilan edilen toplam 1,8 trilyon Euro'luk meblağ, bir yanda COVID19 salgını sonrası toparlanma için kayda değer finansal olanaklar barındırırken, öte yanda 2027 yılına kadar sürecek olan yeni çok yıllı finansal dönem çerçevesinde seferber edilen fonların en az \% 30'unun iklim koruma hedefleri doğrultusunda kullanılması ve bu sayede dekarbonizasyon taahhütlerinin yerine getirilmesi planlanmıştır.

Çalışmada tüm bu boyutlar ve gelişmeler değerlendirildiğinde $\mathrm{AB}^{\prime}$ nin bölgesel/küresel ölçekteki etkinliğini ve küresel iklim eyleminde ağırlık merkezi olma iddiasını sürdürebilmek adına yenilenebilir enerjiye geçiş ve
\end{abstract}


The Budget of the European Union and Green Energy: Perceptions, Actions, and Challenges

enerji arzı güvenliği gibi yaşamsal konuları asli siyasi önceliklerinden biri haline getirdiği ve bu bağlamda ortak bütçeyi koşullandıran iklim modelinin iklim kriziyle mücadelede bir dönüm noktasını temsil ettiği sonucuna varılmıştır. Bununla birlikte Birlik-içi dinamiklerden kaynaklanan zorluklar aşılamadığ1 ve küresel ölçekte yeşil ekonomiye geçişi temsil eden köklü bir dönüşüm gerçekleşmediği takdirde, Yeşil Mutabakat ile hedeflenen dramatik dönüşümün söylemsel olarak iddialı fakat eylemsel olarak belirsiz kalacağı öngörülmüştür. 
